Indonesian Journal of Nutrition and Dietetics Vol. 6, No. 2, 2018: 43-50
Available online at: http://ejournal.almaata.ac.id/index.php/IJND

DOI : http://dx.doi.org/10.21927/ijnd.2018.6(2).43-50

\title{
Effect of "Bento" preparation training on mothers knowledge, skill, and child's picky eating
}

\author{
Carissa Cerdasari ${ }^{1}$, Theresia Puspita ${ }^{2}$, Rany Adelina ${ }^{3}$ \\ ${ }^{123}$ Politeknik Kesehatan Kemenkes Malang \\ Jalan Besar ljen No 77C Malang, Indonesia
}

\begin{abstract}
Background: Picky eating in children may have long-term consequences for growth and development, especially related to underweight. Underweight results on developmental disorder, increase infection susceptibility, disease severity and mortality. One of the causes of picky eating in children is the unattractive of food appearance.

Objectives: To analize the effectiveness of the bento making training, including: Mother's knowledge related to nutrition and feeding difficulty in children; mother's skill in food preparation; and level of eating difficulty in children before and after bento making.

Methods: This study used pretest-posttest design one-group study, mothers $(n=20)$ of preschool-aged 3-6.5 years were recruited from Al-Ghoniya Playgroup and Kindergarten School, Malang. Picky eating in children was determined by Child Eating Behavior Questionnaire (CEBQ) Indonesian version. Studied variables were mother's knowledge and skills, children's satiety responsiveness, slowness in eating, and fussiness. Wilcoxon test and paired t-test were used to assess differences in mother's knowledge and skills, as well as the level of eating difficulty in children before and after the training.

Results: There were differences in maternal knowlege and skills $(p<0.00)$, and also the score of fussiness in children before and after training $(p=0.04)$. No difference was found in satiety responsiveness $(0.058)$ and slowness in eating in children $(p=0.10)$.

Conclusions: Bento-making training is effective to increase mother's knowledge and skill and could be as alternative to overcome picky eating among preschool children, indicated by a decrease in the score of fussines. However, this training couldn't improve the score of satiety responsiveness and slowness in eating.
\end{abstract}

KEYWORDS: bento, picky eater, preschool children

\section{INTRODUCTION}

Malnutrition in children remains public health problem in Indonesia. Although various nutritional improvement programs in the community have been implemented, it they seem unable to fix the situation yet. Moreover, there was an increasing prevalence of child malnutrition in 2013 compared with the previous survey which was $19.6 \%$ in 2010 . The prevalence of severe malnutrition and moderate malnutrition increased by $1.2 \%$ in 2007 to $1.7 \%$ in 2010 (1).

The age of group that is susceptible to malnutrition, is pre-school children aged $3-5$ years old. In this age, children are growing and developing, either physically, cognitively, emotionally and accelerates their new skills quickly. It is a necessary to give appropriate nutrition intake in order to achieve optimal growth and development (2). In addition, pre-school is the time for children to be introduced to variety of healthy foods in order to create positive attitude toward food(3).

Feeding practices in pre-school age children, are not easy thing. At this time there are various problems such as picky eater. Picky eater is defined as a child with several eating behavioral criteria such as feeling full quickly, eating slowly, fussy and picky, lack of response to food, and lack of eating time(4). The prevalence of picky eating among preschool in America was found to be over $50 \%$, consisting of a lack of food variation (58.1\%), rejection of vegetables, fruits, meat and fish $(55.8 \%)$, and preference for certain cooking methods $51.2 \%$ (5). In Indonesia, the prevalence of picky eating among 
preschoolers was found to be $35,4 \%$ in Pekanbaru (6), by $59.3 \%$ in Palembang (7), and $62.9 \%$ in South Minahasa (8).

A study Telaumbanua (2013) showed that the appearance of unattractive foods had an effect on picky eating among preschoolers. Therefore, one of the efforts to improve acceptance of food in children is to serve food to be more interesting in bento-style $(10,11)$. Bento is a Japanese term for meal box usually contains steamed or boiled rice, fried egg, baked fish, fresh salads or pickled vegetables in practical packaging and attractive appearance that can be brought and eaten elsewhere (12). It was found that by displaying bento-style food, the power of acceptance in preschool increased to $92.3 \%$ (13).

Al-Ghoniyya Playgroup and Kindergarten, located in Malang City, is an education model with a wide range of facilities and has the highest grade for school accreditation (A grade). The number of students in this school was relatively large compared to other schools, reaching 180 students. We to determined the level of difficulty of eating at students of Al-Ghoniya Playgroup and Kindergarten in the initial screening, found $28.9 \%$ of children had picky eating especially picky eater. Mothers said that children become fussy while eating, and were often picky eating.

Eating difficulty in children may have longterm consequences for growth and development, especially related to underweight (14). Underweight results on developmental disorders of both intelligence and learning process, more susceptible to infection and increasing disease severity and mortality $(15,16)$.

In accordance with the background that the problem of picky eating in children related to food appearance and there is evidence that this problem could be improved with bento-style food, it is necessary to conduct a research by giving training to the mother in Al-Ghoniyya Playgroup and Kindergarten about eating difficulty in children and how to serve the child's food in the form of bento. Furthermore, this study unvestigated whether there was difference in mother's knowledge, mother skill in making bento, and level of eating difficulty in children before and after training.

\section{MATERIALS AND METHODS}

This study used one-group pretest-posttest design and was conducted in Al-Ghoniya Playgroup and Kindergarten, Malang. Location selection was done purposively based on the recommendation from the education authorities of Malang city because there was a considerable number of students in the Playgroup and Kindergarten, that is 180 students. In addition, Al-Ghoniya Playgroup and Kindergarten had the highest accreditation (A Grade) and had facilities for training implementation. It is also a pilot kindergarten in Malang, so it was very supportive to the activities that impact on improving health and achievement of their students.

Population in this study was all preschool children in Al-Ghoniya Playgroup and Kindergarten, Malang. Meanwhile the subjects were preschool children in Al-Ghoniya Playgroup and Kindergarten who met the inclusion criteria: 1) Categorized as picky eater; 2) Living with mother in one house; 3) Mothers were willing to attend training by signing informed consent.

Screening initial status of picky eater to total student population of Al-Ghoniya Playgroup and Kindergarten $(n=180$ children $)$

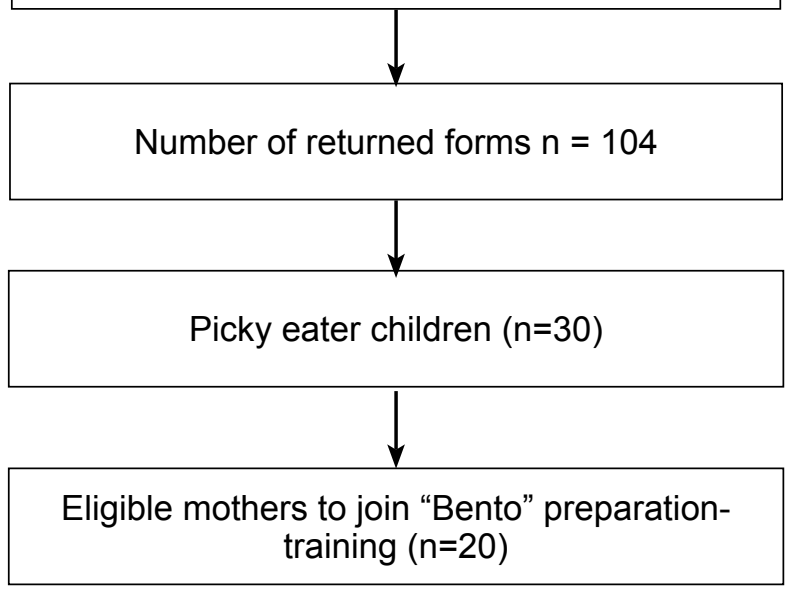

Diagram 1. Stages of selection of samples

Picky eating was measured by five subscores in Child Eating Behavior Questionnaire (CEBQ) that developed in 2001 (17), which fall into two categories: Food Avoidance included Satiety Responsiveness (SR), Slowness in Eating (SE), Fussiness (FF); whereas Food Approach included 
Food Responsiveness (FR), and Enjoyment of Food (EF) using a Likert Scale 1 to 5 ( $1=$ never, $2=$ rare, 3 = sometimes, $4=$ often, 5 = always) (17). Some researches in the Netherlands (4), England (17), and Australia (18) found that CEBQ has shown good psychometric properties such as concurent validity, internal consistency, and test-retest reliability.

The way in which the scoring of CEBQ is shown in Table 1. Scores from each sub-scale group were calculated as mean, and compared. Picky eating was defined where food avoidance was greater than the mean of food approach. This was slightly different from previous studies, Which had strict criteria so that picky eating prevalence was small (4). Determination of picky eating was used in initial screening. Furthermore, difference of eating difficulty level before and after training was determined by food avoidance score, including Satiety Responsiveness (SR), Slowness in Eating (SE), and Fussiness (FF).

Data on maternal characteristics were education and employment. Maternal education was categorized into two categories: 1) Low or Medium: primary to high school education; 2) High: college or university degree. Occupation of mother was categorized into four categories: 1) Civil servant/military/police; 2) Private Employee; 3) Entrepreneurs; 4) Housewife/Not working. Mother's knowledge illustrated how mother's understanding about child nutrition, bento, and eating difficulties in children. Mother's knowledge was measured by a structured questionnaire consisted of 20 multiple choices questions. Higher knowledge scores indicated an improved level of mother's knowledge. Furthermore, mother's skill described mother's ability to prepare children's lunch measured by assessing the mother's lunch box given to the child before and after the training. There were four items of assessment covering portion compliance, menu variation, taste, and appearance. The value for each item was given in the range $0-5$, with higher value represented better skills of mothers to prepare food.

The training provided was bento-making training as an effort to overcome the difficulty of eating in preschool children. It consisted of two stages, which were delivered within two weeks. In the first stage, besides providing the pre-test of mother's initial knowledge, we also delivered material in a class about the introduction of children's eating problems and their solutions, as well as bento sundries and its benefits in improving children's food intake, using power point presentation media, followed by demonstration of bento making. This class and bento making demonstration were delivered by two graduates from Nutrition Department. In the second stage, we delivered material about the appetite-enhancing nutritional substances, food flavors and continued with making bento by the mother. Training closed with post-test of mother's knowledge.

Characteristic data of children included age, sex, and nutritional status. Nutritional status was measured by using weight-for-height Z-Score with the following categories: 1) Overweight: if the value of $z$-score more than $2 \mathrm{SD} ; 2$ ) Normal: the value of z-score obtained between minus 2 SD and 2 SD; 3 ) Underweight: If the value of z-score obtained below - 2SD. Mother's and childs characteristics data were collected by using structured questionnaires, while nutritional status was assessed by anthropometric

Table 1. Scoring for Child Eating Behavior Questionnaire (CEBQ)

\begin{tabular}{lccccc}
\hline \multicolumn{1}{c}{ Positive Statements } & \multicolumn{5}{c}{ Scoring } \\
\cline { 2 - 6 } & $\mathbf{1}$ & $\mathbf{2}$ & $\mathbf{3}$ & $\mathbf{4}$ & $\mathbf{5}$ \\
\hline $\begin{array}{l}\text { Food Avoidance } \\
\text { Satiety Responsiveness (SR) }\end{array}$ & Never & Rare & Sometimes & Often & Always \\
& & & & & \\
$\begin{array}{l}\text { Slowness in eating (SE) } \\
\text { Food Fussiness (FF) }\end{array}$ & & & & & \\
\hline Food Approach & Never & Rare & Sometimes & Often & Always \\
Food Responsiveness (FR) & & & & & \\
Enjoyment of Food (EF) & & & & & \\
\hline
\end{tabular}

Source: Wardle J, Guthrie CA, Sanderson S, Rapoport L. Development of the Children's Eating Behaviour Questionnaire. J Child Psycol Psyciat. 2001;42(7):963-70. 
measurement based on weight for height indicator. Weight and height of children were measured by using digital scales with $0.1 \mathrm{~kg}$ accuracy and microtoise with $0.1 \mathrm{~cm}$ accuracy. Weighing and height measurements were done two times and the mean was calculated. In this study, no interrater reliability was calculated on anthropometric measurements. An anthropometric measurement was performed by two trained enumerators with a background of nutrition education who were assessed to have the same competence in anthropometry measurement.

The collected data were analyzed univariately to see the frequency distribution of the respondent's characteristics, and all the variables, including mean, median and range. Furthermore, bivariate analysis was also performed to see the differences of mother's knowledge and skill, and the eating difficulties level before and after the training. The difference of eating difficulties level before and after training was determined by food avoidance score in CEBQ, that is Satiety Responsiveness (SR), Slowness in Eating (SE), and Fussiness (FF). Differences in maternal knowledge scores and satiety responsiveness scores were tested by using the Wilcoxon test, whereas differences in mother's skill, slowness in eating, and fussines scores were tested using paired t-tests. Data retrieval on the subject of this research was done after they signed informed consent form Reg.No.: 795 / KEPKPOLKESMA/2017.

\section{RESULTS}

\section{Characteristic of participants}

Table 1 shows a description of research subjects based on picky eater status.

Table 1. Frequency distribution of picky eater status

\begin{tabular}{lcc}
\hline \multicolumn{1}{c}{ Category } & $\mathbf{n = 1 0 4}$ & $\%$ \\
\hline Picky eater status & & \\
Yes & 30 & 28.9 \\
Not & 74 & 71.2 \\
\hline
\end{tabular}

The prevalence of picky eater in Al-Ghoniya Playgroup and Kindergarten is determined by the number of feeding questionnaires returned by parents. Of 180 children, 104 children returned the questionnaires that had been distributed and found $28.85 \%$ of children had a picky eater.

At the initial screening found as many as 30 children were experience picky eater. However, only 20 mothers were willing to participate in the research, so the training of bento making as an effort to overcome difficulties to eat in children is done on 20 respondents.

\section{Characteristics of participants}

The mean age of children in this study was $58.65 \pm 10.43$ months, with youngest age is 37 months and the oldest is 71 months. The average child weight is $17.13 \pm 4.76 \mathrm{~kg}$ with the lowest body weight is $12.1 \mathrm{~kg}$ and the highest is $30.3 \mathrm{~kg}$. While the mean height of the child is $105.07 \pm 6.49 \mathrm{~cm}$ with the lowest height is $89.2 \mathrm{~cm}$ and the highest is $113.5 \mathrm{~cm}$. Other children's characteristics are presented in Table 2.

Table 2. Characteristics of Children

\begin{tabular}{ccc}
\hline \multicolumn{1}{c}{ Variables } & $\mathbf{n = 2 0}$ & \% \\
\hline Sex & & \\
Male & 14 & 51.8 \\
$\quad$ Female & 6 & 48.2 \\
Nutritional Status & & \\
Overweight & 2 & 10,0 \\
Normal & 18 & 90.0 \\
Underweight & 0 & 0.0 \\
\hline
\end{tabular}

General characteristics of the mother, presented in Table 3.

Table 3. General characteristics of participants

\begin{tabular}{lcc}
\hline \multicolumn{1}{c}{ Variables } & $\mathbf{n = 2 0}$ & \% \\
\hline Mother's working status & & \\
$\quad$ Not working & 9 & 45 \\
Working & 11 & 55 \\
Mother's educational level & & \\
Low/Medium & 4 & 20 \\
High & 16 & 80 \\
\hline
\end{tabular}

Associated with working mothers, the majority of mothers work as private employees (35.0\%), then as civil servants/military/police and entrepreneurs each $(10.0 \%)$. 


\section{Effect of "Bento" preparation training on mothers knowledge, skill, and child's picky eating}

Differences in the scores of knowledge, skill, and level of picky eating on Al-Ghoniya Playgroup and Kindergarten children are shown in Table 4. The result of Wilcoxon test analysis and paired t-test showed that among the variables studied, there were 3 significant different variables between before and after training, there were scores of knowledge $(p<0.01)$, skill $(p<0.01)$, and score of fussiness $(p=0.04)$. There were no different in scores of satiety responsiveness $(p=0.06)$ and slowness in eating $(p=0.14)$.

Differences in the scores of knowledge and skills of the mother before the after-training showed the effectiveness of the bento-making training. Other results obtained after the bento-making training, there were no differences in score of satiety responsiveness $(p=0.06)$ and slowness in eating $(p=0.10)$, but the score of fussiness showed significance different on children $(p=0.04)$.

\section{DISCUSSION}

There was a difference in the prevalence of picky eater in preschool children in this study compared to similar studies in children aged 2-3 years in Yogyakarta, which amounted to $2.13 \%$ (19). This may because there was a difference in determining the status of a picky eater. Picky eater is defined in may ways, because of it's unclear definitionan. In this study, picky eater is defined as a child whose mean score of food avoidance is higher than the mean score of food approach, based on one research that define picky eater as a combination of low scores on the food approach scales of the CEBQ and high scores on the food avoidance (4). While in the previous study, picky eater was determined by more strict criteria, so the prevalence of picky eater is smaller than in this study (19).

The prevalence of picky etaer in this study was $28.9 \%$. Most of the picky eater children in AIGhoniya Playgroup and Kindergarten had normal nutritional status, and none of the preschoolers were underweight. According to previous study, picky eating in children are associated with underweight status. However, this has not been seen in preschool children in the study sites. This is likely due to eating difficulty that experienced by children has not lasted for a long time, so did not give any effect on the decline in nutritional status. It is said that children who at 2.5 years old were picky eater, are twice as likely to have less weight when they are 4.5 years old. The study showed changes in nutritional status due to difficulty eating takes a relatively long time (14).

Previous research showed that working mother with high position, having children with poorer intakes. Similarly, several other studies revealed the effect of maternal working status on the child's dietary intake and nutritional status (20).

"Bento" preparation training improved mother's knowledge and skill related to child eating difficulty and meal preparation. In the first meeting of this training, some material was delivered using audio visual media to give an overview to mothers about eating difficulties in children, some substances in food that can increase appetite of children, and the introduction of "bento". In the next meeting, demonstrations were perfomed to show mothers how to plan menus, cook, form, and arrange "bento" in children's luncbox or plate. In the end of the training, all mothers were comitted to give "bento" for their children as an alternative to overcome picky eating

Table 4. Differences scores of knowledge, skills, and difficulty level of feeding children before and after training $(\mathbf{N}=\mathbf{2 0})$

\begin{tabular}{|c|c|c|c|}
\hline Variables & Before & After & $\mathbf{p}$ \\
\hline Score of knowledge * & $45(30-85)$ & $75(55-95)$ & $<0.00$ \\
\hline Score of skills ${ }^{* *}$ & $5.7(2.08)$ & $8.45(2.06)$ & $<0.00$ \\
\hline Score of satiety responsiveness ${ }^{*}$ & $16.5(7-19)$ & $12(10-19)$ & 0.06 \\
\hline Score of slowness in eating ${ }^{* *}$ & $11.41(3.17)$ & $9.83(2.29)$ & 0.10 \\
\hline Score of fussiness ${ }^{\star *}$ & $20.83(4.28)$ & $18.17(4.76)$ & 0.04 \\
\hline
\end{tabular}

*Wilcoxon test: median (min-max) ** paired t-test: mean (SD) 
in children. Results of this study were in line with the previous studies which showed the effectiveness of a nutritional education using audio-visual media and modeling approach which one of the methods is by cooking demonstration and practice, that demonstrated by positive changes in knowledge and skills after education (21). In addition, because at the time of training most mothers brought their children, so the children were also exposed to the training materials and also watched the "bento" making demonstration. Children become interested in the "bento" made. Some studies revealed that cooking class and home food preparation intervention had positive impact on adult's healthier food intake (22), and on children's food-related preferences, attitudes, and behaviors (23).

One study in Dubai, showed that mother's better knowledge about nutrition and food preferences and nutrition, will increase children's food intake (20). In addition, mother skills in bento making, could improve the appearance of foods that can ultimately have an impact on increasing food acceptance and decrease fussiness in children. This is in accordance with previous study which found that by displaying bento-style meals, the preschooler's food acceptance increased to $92.3 \%$ (13).

However, this study found no differences in satiety responsiveness and slowness in eating score. Satiety responsiveness and slowness in eating was associated with lower energy intake $(16,21)$. Notably, satiety responsiveness has been associated with lower BMI $(18,24)$. Monitoring feeding that practiced by parents have a contribution to satiety responsiveness in children (25). In this type of feeding practice, mother or caregiver mostly or always keep tract of the sweets, snack food, and high-fat food that children eat (26). This study did not provide evaluation and intervention in parental feeding practice, so there were no difference in satiety responsiveness and slowness in eating score before and after training.

\section{CONCLUSION AND RECOMMENDATION}

Mother's knowledge and skill related to childs eating difficulty, bento, and bento preparation for preschool children had increased after the training.
In addition, the training also contributed the decline of childs fussiness score. However, there were no effect on childs satiety responsiveness and slowness. This may depends on each parental feeding practice while we did not intervene on it. The better of food appearance tend to decrease the fussiness. It is due to the attractive appearance in "bento", that makes children more interested to eat and finish the food served.

Bento-making training is effective in improving mother's knowledge and skill and may decrease eating difficulties in children. However, this training couldn't improve scores of satiety responsiveness and slowness in eating, so we suggest for further research to give intervention associated with parental feeding practices.

\section{ACKNOWLEDGEMENTS}

Thanks to all teachers, parents, and children from Al-Ghoniyya Playgroup and Kindergarten who participated in the research. Moreover, we were grateful for a good cooperation was established by our enemeurators (Gita Martha Vindiarti and Ella Rizqining Firdaus) and also Health Polytechnic of Malang who supported this study financially.

\section{REFERENCES}

1. Balitbangkes Kemenkes RI. Riset Kesehatan Dasar 2013. Jakarta; 2013.

2. Branca F, Piwoz E, Schultink W, Sullivan LM artine. Nutrition and health in women, children, and adolescent girls. BMJ. 2015;351(November):h4173.

3. Contento et al. Chapter 3 Nutrition education for preschool children. J Nutr Educ. 1995;27(6):2917.

4. Tharner A, Jansen PW, Jong JCK, Moll HA, Ende J Van Der, Jaddoe VW V, et al. Toward an operative diagnosis of fussy / picky eating : a latent profile approach in a populationbased cohort. Int J Behav Nutr Phys Act. 2014;11(14):1-11.

5. Shim JE, Kim J, Mathai RA. Associations of infant feeding practices and picky eating 
behaviors of preschool children. J Am Diet Assoc. 2011 Sep;111(9):1363-8.

6. Kesuma A, Novayelinda R, Sabrian F. Faktorfaktor yang berhubungan dengan perilaku kesulitan makan anak prasekolah. J Online Mhs. 2015;2(2):953-61.

7. Fitriani F, Febry F, Mutahar R. Gambaran Penyebab Kesulitan Makan pada Anak Prasekolah Usia 3-5 Tahun di Perumahan Top Amin Mulya Jakabaring Palembang Tahun 2009. J Publ IIm Fak Kesehat Masy Univ Sriwij. 2009;

8. Karaki KB, Kundre R, Karundeng M. Hubungan Pola Asuh Ibu dengan Perilaku Sulit Makan pada Anak Usia Prasekolah (3-5 Tahun) di Taman Kanak-Kanak Desa Palelon Kec. Modoinding Minahasa Selatan. ejournal Keperawatan (eKp). 2016;4(1):1-7.

9. Telaumbanua LK. Faktor-faktor yang mempengaruhi sulit makan pada usia prasekolah di TK Islam Nurul Hikmah Bantar Gebang Bekasi. Bekasi; 2013.

10. Rudianto. Pengaruh Penyajian Diet dalam Bentuk Karakter Bento terhadap Tingkat Konsumsi pada Anak Usia 3-5 Tahun di Ruang Rawat Inap Rumah Sakit Petrokimia Gresik. Universitas Airlangga; 2015.

11. Widyaningtyas F. Pengaruh Penyajian Ala Bento dengan Persepsi dan Daya Terima Pasien di Bangsal Anak RSUP DR. Sardjito. Universitas Gadjah Mada; 2013.

12. Nishimoto H, Hamda A, Takai Y, Goto A. Investigation of decision process for purchasing foodstuff in the "Bento" lunch box. Procedia Manuf 3. 2015;472-9.

13. Lestari WB. Pengaruh Penyajian Makanan Ala Bento terhadap Daya Terima Anak Prasekolah di TK Bina Anak Sholeh Yogyakarta. Universitas Gadjah Mada; 2014.

14. Dubois L, Farmer A, Girard M, Peterson K, Tatone-tokuda F. Problem eating behaviors related to social factors and body weight in preschool children : A longitudinal study. Int J Behav Nutr Phys Act. 2007;4(9):1-10.

15. Ekstein S, Laniado D, Glick B. Does picky eating affect weight-for-length measurements in young children? Clin Pediatr (Phila). 2010 Mar;49(3):217-20.

16. Ali SS. A brief review of risk-factors for growth and developmental delay among preschool children in developing countries. Adv Biomed Res. 2013;2:91.

17. Wardle J, Guthrie CA, Sanderson S, Rapoport L. Development of the Children's Eating Behaviour Questionnaire. J Child Psycol Psyciat. 2001;42(7):963-70.

18. Mallan KM, Nambiar S, Magarey AM, Daniels LA. Satiety responsiveness in toddlerhood predicts energy intake and weight status at four years of age. Appetite [Internet]. 2014;74:79-85. Available from: http://dx.doi.org/10.1016/j. appet.2013.12.001

19. Cerdasari C, Helmyati S, Julia M. Tekanan untuk makan dengan kejadian picky eater pada anak usia 2-3 tahun. J Gizi Klin Indones. 2017;13(4):170-8.

20. Al-Shookri A, Al-Shukaily L, Hassan F, AlSheraji S, Al-Tobi S. Effect of mothers nutritional knowledge and attitudes on Omani children's dietary intake. Oman Med J. 2011;26(4):253-7.

21. Wirawan S, Abdi LK, Sulendri NKS. Penyuluhan Dengan Media Audio Visual Dan Konvensional Ter- Hadap Pengetahuan Ibu Anak Balita. J Kesehat Masy. 2014;10(1):80-7.

22. Reicks M, Trofholz AC, Stang JS, Laska MN. Impact of cooking and home food preparation interventions among adults: outcomes and implications for future programs. J Nutr Educ Behav. 2014;46(1):1-23.

23. Hersch D, Perdue L, Ambroz T, Boucher JL. The Impact of Cooking Classes on Food-Related Preferences, Attitudes, and Behaviors of SchoolAged Children: A Systematic Review of the Evidence, 2003-2014. Prev Chronic Dis [Internet]. 2014;11(2):140267. Available from: http://www. cdc.gov/pcd/issues/2014/14_0267.htm

24. Carnell S, Wardle J. Appetite and adiposity in children: Evidence for a behavioral susceptibility theory of obesity. Am J Clin Nutr. 2008;88(1):22-9.

25. Jansen PW, Roza SJ, Jaddoe VWV, Mackenbach JD, Raat H, Hofman A, et al. Children's eating 
behavior, feeding practices of parents and weight problems in early childhood: Results from the population-based Generation R Study. Int J Behav Nutr Phys Act [Internet]. 2012;9(1):1. Available from: International Journal of Behavioral Nutrition and Physical Activity
26. Birch LL, Fisher JO, Grimm-thomas K, Markey CN, Sawyer R, Johnson SL. Confirmatory factor analysis of the Child Feeding Questionnaire : a measure of parental attitudes, beliefs and practices about child feeding and obesity proneness. Appetite. 2001;36:201-10. 